\section{Validating Technology-Organization-Environment (TOE) Framework in Web 2.0 Adoption in Supply Chain Management}

By: Tarofder, AK (Tarofder, Arun Kumar) ${ }^{[1]}$; Jawabri, A (Jawabri, Adnan) ${ }^{[2]}$; Haque, A (Haque, Ahasanul) ${ }^{[3]}$; Sherief, SR (Sherief, Sultan Rehman) $^{[1]}$

\section{INDUSTRIAL ENGINEERING AND MANAGEMENT SYSTEMS}

Volume: 18 Issue: 3 Pages: $482-494$

DOI: $10.7232 /$ iems.2019.18.3.482

Published: SEP 2019

Document Type: Article

\section{Abstract}

The second stage of Internet revolution has started with Web 2.0, which allows users to generate and develop the content without code. Web 2.0 not only change the way individual use internet but also tremendously transformed business activities. The primary aims of this study are (a) to validate the TOE framework in understanding Web 2.0 adoption in an organizational context, and (b) measuring the importance of each variable from the different industry perspective. This study developed a conceptual model based on the Technology-Organization-Environment (TOE) framework. A Web-based structured questionnaire was developed to collect primary data. With three months effort, this study managed to get 205 respondents from Malaysian manufacturing and service industry. Multiple regression and Dominance analysis were applied to understand the effect of the TOE framework on Web 2.0 adoption and predicting the importance of each factor form different industries perspective respectively. Multiple regression results confirmed that all the factors are important for Web 2.0 adoption, however, the technological characteristic is the most important determinant for Web 2.0 adoption. Moreover, dominance analysis showed very interesting results that relative advantage is not important for the service industry but top management support is the utmost importance. Similarly, results also indicated that top management support plays important role in Web 2.0 adoption for the fewer experience companies pertaining to internet usage. This study is one of the very few that provides insightful information regarding the effect of the TOE on Web 2.0 adoption in the supply chain management system. This study would be the guideline for the managers of both the manufacturing and service industry in order to implement the Web 2.0 in their supply chain system.

\section{Keywords}

Author Keywords: Web 2.0; Adoption; TOE Framework; Perceived Ease of Use; Perceived Usefulness; Competitive Pressure

KeyWords Plus: BIG DATA ANALYTICS; RELATIVE IMPORTANCE; INTERNET; PERFORMANCE; THINGS; DETERMINANTS; INFORMATION; MODEL; INTEGRATION; PREDICTORS

\section{Author Information}

Reprint Address: Tarofder, AK (reprint author)

Management \& Sci Univ, Fac Business Management \& Profess Studies, Shah Alam, Malaysia. Addresses:

\footnotetext{
[ 1] Management \& Sci Univ, Fac Business Management \& Profess Studies, Shah Alam, Malaysia

[2] Al Khawarizmi Int Coll, Abu Dhabi, U Arab Emirates

[ 3] Int Islamic Univ, Dept Business Adm, Islamabad, Pakistan
}

E-mail Addresses: arun_kumar@msu.edu.my

Publisher

KOREAN INST INDUSTRIAL ENGINEERS, VICTORIA BLDG RM 509, 705-1 YEOKSAM-DONG, KANGNAM-GU, SEOUL, 135-080, SOUTH KOREA

\section{Categories / Classification}

Research Areas: Engineering

Web of Science Categories: Engineering, Industrial

See more data fields

\section{Cited References: 104}

Showing 30 of $104 \quad$ View All in Cited References page

1. Change, customer satisfaction and competition: Issues from the strategic management context By: Adewale, A. A.

International Journal of Economics, Business and Management Studies Volume: 3 Issue: 2 Pages: 55-66 Published: 2016

2. Study of Relation between Business Model and Sensemaking Decisions By: Ahmadi, F; Rahimi, M; Rezaei, A.

\section{Citation Network}

In Web of Science Core Collection

0

Times Cited

Create Citation Alert

\section{4}

Cited References

View Related Records

Use in Web of Science

Web of Science Usage Count

1 1

Last 180 Days $\quad$ Since 2013

Learn more

This record is from:

Web of Science Core Collection

- Emerging Sources Citation Index

Suggest a correction

If you would like to improve the quality of the data in this record, please suggest a correction.
What is the most important thing Wos helps you accomplish (what can you not live without)?

Find potential jobs (lab of interest, Key Pl's in my field)

Find new articles in my field

Set up an alert for new articles in my field

Look for articles all from the same institution institution

Prepare a dataset for export to InCites 
By: Ahsan, M. N.; Shah Alam, S.

Journal of Internet Banking and Commerce Volume: 12 Issue: 3 Pages: 1-11 Published: 2007

4. Title: [not available]

By: Ajzen, I.

From intentions to actions: A theory of planned behavior Action control Pages: 11-39 Published: 1985

Publisher: Springer, Berlin, Germany

5. THE THEORY OF PLANNED BEHAVIOR

By: AJZEN, I

ORGANIZATIONAL BEHAVIOR AND HUMAN DECISION PROCESSES Volume: 50 Issue: 2 Pages: 179-211 Published: DEC 1991

6. Relevance of Stakeholders Theory, Organizational Identity Theory and Social Exchange Theory to Corporate Social Responsibility and Employees Performance in the Commercial Banks in Nigeria

By: Albasu, J; Nyameh, J.

International Journal of Business, Economics and Management Volume: 4 Issue: 5 Pages: 95-105 Published: 2017

7. Radio frequency identification (RFID) technology as a strategic tool towards higher performance of supply chain operations in textile and apparel industry Times Cited: 8 of Malaysia

By: Ali, A; Haseeb, M.

Uncertain Supply Chain Management Volume: 7 Issue: 2 Pages: 215-226 Published: 2019

8. $\quad$ Risk Assessment of Ex-Post Transaction Cost in Construction Projects Using Structural Equation Modeling

Times Cited: 2

By: Ali, Zaigham; Zhu, Fangwei; Hussain, Shahid

SUSTAINABILITY Volume: 10 Issue: 11 Article Number: 4017 Published: NOV 2018

9. The Impact of Training and Development on Workers Performance in Imo State

Times Cited: 3

By: Anyanwu, JO; Okoroji, LI; Ezewoko, OF; et al.

Global Journal of Social Sciences Studies Volume: 2 Issue: 2 Pages: 51-71 Published: 2016

[Show additional data]

10. An exploratory study on supply chain analytics applied to spare parts supply chain

Times Cited: 6

By: Arya, Vedpal; Sharma, Pankaj; Singh, Ashwani; et al.

BENCHMARKING-AN INTERNATIONAL JOURNAL Volume: 24 Issue: 6 Pages: 1571-1580 Published: 2017

11. B2B technology adoption in customer driven supply chains

Times Cited: 13

By: Asare, Anthony K.; Brashear-Alejandro, Thomas G.; Kang, Jun

JOURNAL OF BUSINESS \& INDUSTRIAL MARKETING Volume: 31 Issue: 1 Pages: 1-12 Published: 2016

12. Integrated technology-organization-environment (T-O-E) taxonomies for technology adoption

Times Cited: 8

By: Awa, Hart O.; Ojiabo, Ojiabo Ukoha; Orokor, Longlife E.

JOURNAL OF ENTERPRISE INFORMATION MANAGEMENT Volume: 30 Issue: 6 Pages: 893-921 Published: 2017

13. Integrating TAM, TPB and TOE frameworks and expanding their characteristic constructs for e-commerce adoption by SMEs By: Awa, Hart Okorie; Ojiabo, Ojiabo Ukoha; Emecheta, Bartholomew Chinweuba

JOURNAL OF SCIENCE AND TECHNOLOGY POLICY MANAGEMENT Volume: 6 Issue: 1 Pages: 76-94 Published: 2015

14. Analysis of technological, individual and community factors influencing the use of popular Web 2.0 tools in LIS education

By: Barhoumi, Chokri

ELECTRONIC LIBRARY Volume: 35 Issue: 5 Pages: 977-993 Published: 2017

15. Second-life retailing: a reverse supply chain perspective

By: Beh, Loo-See; Ghobadian, Abby; He, Qile; et al.

SUPPLY CHAIN MANAGEMENT-AN INTERNATIONAL JOURNAL Volume: 21 Issue: 2 Pages: 259-272 Published: 2016

16. Coping with family-to-work conflict: the role of informal work accommodations to family.

By: Behson, Scott J

Journal of occupational health psychology Volume: 7 Issue: 4 Pages: 324-41 Published:2002-Oct

17. Beyond global measures of relative importance: Some insights from dominance analysis

By: Budescu, DV; Azen, R

ORGANIZATIONAL RESEARCH METHODS Volume: 7 Issue: 3 Pages: 341-350 Published: JUL 2004

18. DOMINANCE ANALYSIS - A NEW APPROACH TO THE PROBLEM OF RELATIVE IMPORTANCE OF PREDICTORS IN MULTIPLE-REG BY: BUDESCU, DV

PSYCHOLOGICAL BULLETIN Volume: 114 Issue: 3 Pages: 542-551 Published: NOV 1993 
19. E-grocery supply chain management enabled by mobile tools

By: Cagliano, Anna Corinna; De Marco, Alberto; Rafele, Carlo

BUSINESS PROCESS MANAGEMENT JOURNAL Volume: 23 Issue: 1 Pages: 47-70 Published: 2017

20. An Eye-gaze Tracking System for Teleoperation of a Mobile Robot.

Times Cited: 3

By: Carreto, C.; Gego, D.; Figueiredo, L.

Journal of Information Systems Engineering \& Management Volume: 3 Issue: 2 Pages: 16 Published: 2018

21. The influence of information technology and communication supply chain management performance for greater SME manufacturing in aguascalientes

Times Cited: 3

By: Castorena, O. H.; Enriquez, L. A.; Adame, M. G.

International Journal of Business, Economics and Management Volume: 1 Issue: 12 Pages: 382-396 Published: 2014

22. eReadiness of public university libraries in Malawi to use mobile phones in the provision of library and information services

Times Cited: 1

By: Chaputula, Aubrey Harvey; Mutula, Stephen

LIBRARY HI TECH Volume: 36 Issue: 2 Pages: 270-288 Published: 2018

23. Factors affecting e-business adoption in SMEs: an empirical research

Times Cited: 10

By: Chatzoglou, Prodromos; Chatzoudes, Dimitrios

JOURNAL OF ENTERPRISE INFORMATION MANAGEMENT Volume: 29 Issue: 3 Pages: 327-358 Published: 2016

24. Impact of operational risk toward the efficiency of banking-evidence from Taiwans banking industry

Times Cited: 2

By: Cheng, C. P.; Phung, M. T.; Hsiao, C. L.; et al.

Asian Economic and Financial Review Volume: 8 Issue: 6 Pages: 815-831 Published: 2018

[Show additional data]

25. m-commerce technology adoption: Thematic and citation analysis of scholarly research during (2008-2017)

Times Cited: 2

By: Chhonker, Mayanka Singh; Verma, Deepak; Kar, Arpan Kumar; et al.

BOTTOM LINE Volume: 31 Issue: 3-4 Pages: 208-233 Published:2018

26. Oguamalam Masquerade Performance beyond Aesthetics

Times Cited: 3

By: Chielotam, AN

Humanities and Social Sciences Letters Volume: 3 Issue: 2 Pages: 63-71 Published: 2015

27. Risk and return analysis of closed-end mutual fund in Bangladesh

Times Cited: 2

By: Chowdhury, T. S.; Habibullah, M.; Nahar, N.

Journal of Accounting, Business and Finance Research Volume: 3 Issue: 2 Pages: 83-92 Published: 2018

28. User acceptance of computer technology: A comparison of two theoretical models

Times Cited: 3

By: Davis, F. D.; Bagozzi, R. P.; Warshaw, P. R.

Management Science Volume: 35 Pages: 982-1003 Published: 1986

29. RFID in US hospitals: an exploratory investigation of technology adoption

Times Cited: 10

By: Dey, Asoke; Vijayaraman, B. S.; Choi, Jeong Hoon

MANAGEMENT RESEARCH REVIEW Volume: 39 Issue: 4 Pages: $399-424$ Published: 2016

30. Strategic supply chain framework as an effective approach to procurement of public construction projects in Nigeria By: Dim, N. U.; Ezeabasili, A. C. C.

International Journal of Management and Sustainability. Volume: 4 Issue: 7 Pages: 163-172 Published: 2015

Showing 30 of $104 \quad$ View All in Cited References page

Find new articles in my field

Set up an alert for new articles in my

Look for articles all from the same institution

Prepare a dataset for export to InCites 